\title{
Combination of half-dose photodynamic therapy and anti-VEGF versus anti-VEGF monotherapy for polypoidal choroidal vasculopathy
}

Jun Yong Chow ${ }^{1,2}$, Poh Fong She ${ }^{1,2}$, Mae-Lynn Catherine Bastion ${ }^{1}$, Wan Norliza Binti Wan Muda ${ }^{2}$

${ }^{1}$ Department of Ophthalmology, Universiti Kebangsaan Malaysia Medical Centre, Kuala Lumpur, Malaysia; ${ }^{2}$ Department of Ophthalmology, Hospital Tengku Ampuan Afzan, Kuantan, Pahang, Malaysia

\section{Abstract}

Introduction: Polypoidal choroidal vasculopathy (PCV) is an abnormality of the inner choroidal vasculature. The recommended treatment for PCV is a combination of standard verteporfin photodynamic therapy (PDT) with intravitreal injections of anti-vascular endothelial growth factor (anti-VEGF). There have been reports of success with combination of half-dose PDT (hd-PDT) and anti-VEGF in the treatment of PCV. hd-PDT might be a cost-effective method with favourable outcome in the treatment of PCV and fewer side effects.

Purpose: To explore the efficacy of hd-PDT combined with anti-VEGF and anti-VEGF monotherapy in PCV.

Study design: Retrospective nonrandomized comparative study.

Material and methods: We conducted a retrospective nonrandomized comparative records review of all patients with PCV received a combination of hd-PDT and anti-VEGF vs anti-VEGF monotherapy from November 2017 to November 2019 at

Correspondence: Professor. Dr. Mae-Lynn Catherine Bastion, DrOphth (UKM), Department of Ophthalmology, Faculty of Medieine, Universiti Kebangsaan Malaysia Medical Centre, Jalan Yaacob Latif, Bandar Tun Razak, 56000 Kuala Lumpur, Wilayah Persekutuan Kuala Lumpur, Malaysia.

E-mail:mae-lynn@ppukm.ukm.edu.my 
Hospital Tengku Ampuan Afzan, Pahang, Malaysia. Patients received a half-dose of verteporfin over 10 minutes and were irradiated by the standard fluence combined with intravitreal ranibizumab or aflibercept injections. The monotherapy group received either intravitreal ranibizumab or aflibercept. Primary outcome measures were best-corrected visual acuity (BCVA) and central subfield thickness (CST) at 6 months post-treatment. Secondary outcome measure was documentation of side effects.

Results: The study included a total of 16 patients, with 8 patients (8 eyes) in the combination group and 8 patients (10 eyes) in the monotherapy group. At 6 months post-treatment, the BCVA changes in logarithm of the minimum angle of resolution (logMAR) were -0.06 in the combination group and +0.02 in the monotherapy group ( $p=0.928)$. The average CST reduction was $51.6 \mu \mathrm{m}$ in the combination group and $106.1 \mu \mathrm{m}$ in the monotherapy group $(p=0.214)$. One eye developed subretinal haemorrhage after hd-PDT and one eye developed retinal atrophy in the monotherapy group.

Conclusion: hd-PDT combined with anti-VEGF was able to produce similar functional outcomes in terms of BCVA when compared to anti-VEGF monotherapy. However, monotherapy is shown to be superior to combination treatment for anatomical improvement.

Keywords: anti-vascular endothelial growth factor, half-dose photodynamic therapy, polypoidal choroidal vasculopathy, verteporfin

\section{Abstrak}

Pengenalan: Vaskulopati koroidal polypoidal ('polypoidal choroidal vasculopathy'(PCV)) adalah melibatkan keabnormalan pada lapisan dalam jaringan salur darah koroidal. Rawatan lazim yang disyorkan untuk PCV adalah kombinasi terapi fotodinamik verteporfin (photodynamic therapy (PDT)) dengan suntikan faktor pertumbuhan endothelial anti-vaskular (anti-VEGF) ke dalam mata. Terdapat kajian tentang kejayaan kombinasi PDT separuh dos (hd-PDT) dan anti-VEGF dalam rawatan PCV. hd-PDT mungkin satu kaedah yang menjimatkan kos tetapi pada masa yang sama berkesan dalam rawatan PCV dengan sampingan yang minimum.

Tujuan: Untuk meneroka keberkesanan kombinasi hd-PDT dan anti-VEGF dengan monoterapi anti-VEGF dalam PCV rawatan.

Reka bentuk kajian: Kajian perbandingan retrospektif tanpa rawak

Kaedah kajian: Satu tinjauan rekod retrospektif terhadap semua pesakit PCV yang menerima kombinasi hd-PDT dan anti-VEGF berbanding dengan monoterapi anti-VEGF dari November 2017 hingga November 2019 di Hospital Tengku Ampuan Afzan, Pahang, Malaysia. Pesakit menerima verteporfin separuh dos selama 10 
minit dan disinari oleh kelancaran piawai yang digabungkan dengan suntikan intravitreal ranibizumab atau aflibercept. Kumpulan monoterapi adalah pesakit yang menerima ranibizumab intravitreal atau aflibercept sahaja. Hasil utama kajian adalah penglihatan (BCVA) dan ketebalan pusat tengah (CST) pada 6 bulan selepas rawatan. Kesan sampingan juga didokumentasi.

Hasil kajian: Kajian ini merangkumi sejumlah 16 pesakit, dengan 8 pesakit (8 mata) dalam kumpulan kombinasi dan 8 pesakit (10 mata) dalam kumpulan monoterapi. Pada 6 bulan selepas rawatan, perubahan BCVA dalam logMAR adalah -0.06 pada kumpulan kombinasi dan +0.02 pada kumpulan monoterapi $(p=0.928)$. Pengurangan CST purata ialah $51.6 \mu \mathrm{m}$ pada kumpulan kombinasi dan 106.1 $\mu \mathrm{m}$ pada kumpulan monoterapi $(p=0.214)$. Satu mata mengalami pendarahan subretinal selepas hd-PDT manakala satu mata mengalami penipisan saraf mata pada kumpulan monoterapi.

Kesimpulan: Kombinasi hd-PDT dengan anti-VEGF memberi kesan yang sama dengan monoterapi anti-VEGF dari segi penglihtan. Manakala, rawatan monoterapi memberi pemulihan anatomi yang lebih berkesan daripada rawatan kombinasi.

Kata kekunci: faktor pertumbuhan endothelial anti-vaskular, polypoidal choroidal vasculopathy, terapi fotodinamik verteporfin yang separuh dos, verteporfin

\section{Introduction}

Polypoidal choroidal vasculopathy (PCV) is an abnormality of the inner choroidal vasculature. It is a subtype of neovascular age-related macular degeneration (nAMD), and typically affects darker-skinned ethnicities such as Asians and African Americans. It is characterized by serosanguinous pigmented epithelium detachments and exudative changes leading to subretinal fibrosis and haemorrhage in multiple retinal layers. ${ }^{1} \mathrm{PCV}$ may be underdiagnosed in people who are not Asian, as indocyanine green angiography (ICGA) is not routinely performed in non-Asian countries.

There are various treatment options for PCV, including photodynamic therapy (PDT), anti-vascularendothelial growth factor(VEGF) monotherapy, and combination therapy. PDT with verteporfin (VPDT) is the first widely used treatment for PCV and it helps in polyp regression. ${ }^{2}$ Standard PDT is the energy delivery dose of $50 \mathrm{~J} / \mathrm{cm}^{2}$, irradiance of $600 \mathrm{~mW} / \mathrm{cm} 2$ of $689 \mathrm{~nm}$ light over 83 seconds with a verteporfin dose of $6 \mathrm{mg} / \mathrm{m}^{2}$. In the era of anti-VEGF, many studies such as ANCHOR, MARINA, and VIEW 1 and VIEW 2 have shown that intravitreal ranibizumab or aflibercept injections are the standard treatment for nAMD. ${ }^{3-5}$ Based on the PLANET study, aflibercept with sham VPDT is noninferior to aflibercept with rescue VPDT at 52 weeks in PCV treatment. ${ }^{6}$ The LAPTOP study from Japan showed ranibizumab to be more effective than PDT for treatment-naïve PCV.? In EVEREST I and II, combination therapy of 
VPDT and ranibizumab was shown to be superior to ranibizumab monotherapy in terms of best-corrected visual acuity (BCVA), complete polyp regression, and number of anti-VEGF injections required in a year. ${ }^{8,9}$ Much evidence supports that PDT and anti-VEGF treatment are effective in treating symptomatic patients with PCV to the point of complete regression and without severe vision loss. However, VPDT carries risks of recurrent haemorrhages, exudation, choroidal ischemia, and retinal atrophy. ${ }^{10}$

Various 'safety-enhanced' VPDT protocols have been revised to optimise treatment outcomes and reduce its side effects, typically using half-dose verteporfin (verteporfin $3 \mathrm{mg} / \mathrm{m}^{2}$ ) or half-fluence vPDT (laser fluence $25 \mathrm{~J} / \mathrm{cm}^{2}$ ). Wong et al. has shown that half-dose PDT can lead to polyp regression and produces similar results as standard PDT. ${ }^{11,12}$ Meanwhile, several studies have demonstrated reduced fluence PDT was able to control the disease successfully. ${ }^{13,14}$ In a study Nicolo et al., hd-PDT was found to be more effective than half-fluence PDT for central serous chorioretinopathy. ${ }^{15} \mathrm{~A}$ study by William et al. found that intravitreal ranibizumab monotherapy and combination of half-fluence PDT with ranibizumab in the treatment of nAMD appeared to have similar efficacy. ${ }^{16}$ However, there were no studies looking into the outcome between combination of hd-PDT with anti-VEGF injection and anti-VEGF injection alone in the treatment of PCV. Thus, this study was conducted to compare the outcomes between hd-PDT combined with anti-VEGF and anti-VEGF monotherapy.

\section{Material and methods}

This is a retrospective, nonrandomized, comparative review of the medical records of PCV patients who received combination of hd-PDT and anti-VEGF or anti-VEGF monotherapy from November 2017 to November 2019 at Hospital Tengku Ampuan Afzan, Pahang, Malaysia. This study was approved by the Medical Research and Ethics Committee, Ministry of Health Malaysia with the National Medical Research Register number (NMRR-20-609-54356).

A diagnosis of PCV was confirmed by indocyanine green angiography (ICGA) with the Heidelberg Retina Angiograph (Heidelberg Engineering, Heidelberg, Germany) based on the EVEREST trial ${ }^{17}$ or optical coherence tomography (OCT) suggestive of PCV features. Patients who received treatment previously with vPDT, pneumatic displacement of submacular haemorrhage, or focal laser photocoagulation were excluded, as well as patients who had other macular pathologies such as myopic maculopathy, retinal detachment, and macular hole.

Patients received half the standard dose of $3 \mathrm{mg} / \mathrm{m}^{2}$ verteporfin (Visudyne; Novartis Pharma AG, Basel, Switzerland) over 10 minutes and were irradiated by the standard fluence $(50 \mathrm{~J} / \mathrm{cm} 2,83 \mathrm{~s}, 600 \mathrm{~mW} / \mathrm{cm} 2$ at $689 \mathrm{~nm})$ combined with three loading doses of either intravitreal ranibizumab $(0.5 \mathrm{mg} / 0.05 \mathrm{ml}$, Lucentis; Novartis 
Pharma AG, Basel, Switzerland) or intravitreal aflibercept $(2 \mathrm{mg} / 0.05 \mathrm{ml}$, Eylea; Bayer, Leverkusen, Germany). The laser spot size was added $1,000 \mathrm{~mm}$ to the entire PCV lesion, including any polyps and branching vascular networks (BVN) as seen on ICGA. This included the subfoveal area for some patients. Another group of patients received either intravitreal ranibizumab or aflibercept. For the monotherapy group, they were given three loading doses of anti-VEGF followed by "pro re nata" (PRN) regimen depending on disease activity such as visual acuity, OCT changes, or new symptoms. Patients were examined at baseline and followed up until 6 months after treatment. Primary outcome measures were changes in BCVA and central subfield thickness (CST) by OCT (Spectral Domain Cirrus OCT Model 4000, Carl Zeiss Meditech, Jena, Germany) at 6 months post-treatment. Secondary outcome measure was documentation of side effects. The number of re-treatments with either hd-PDT or intravitreal anti-VEGF injection during these 6 months were also evaluated.

\section{Results}

A total of 20 eyes of 18 patients were diagnosed as PCV and treated either with combination of hd-PDT and anti-VEGF or anti-VEGF alone. Eight patients underwent combination therapy while 10 patients were in the anti-VEGF monotherapy group. However, among the 10 patients in the monotherapy group, two patients were excluded as one patient defaulted follow-up and we were unable to obtain a clear image on OCT due to breakthrough vitreous haemorrhage in another patient. Thus, we studied the medical records from these 16 patients (18 eyes), with 8 patients ( 8 eyes) in the combination group and 8 patients (10 eyes) in the monotherapy group.

Mean age was 70 years in the combination group and 69.7 years in the monotherapy group; there were an equal number of males and females in each group. The proportion of left eyes was greater than right eyes, with a ratio of 2:6 in the hd-PDT group and 4:6 in the anti-VEGF group. The number of treatment-naïve patients were three in the hd-PDT group and seven in monotherapy group. Other patients had a history of previous anti-VEGF treatment. The mean number of previous anti-VEGF treatments was $4.1 \pm 3.9$ ranibizumab injections (range, 0-10 injections) and $0.3 \pm 0.7$ aflibercept injections (range, $0-2$ injections) in the hd-PDT group, while in the anti-VEGF monotherapy group it was $0.9 \pm 1.5$ ranibizumab injections (range, $0-4$ injections) and $0.4 \pm 0.8$ aflibercept injections (range, $0-2$ injections). Five patients from the combination hd-PDT and anti-VEGF group had $\mathrm{BVN}$, whereas none of the patients in the monotherapy group had BVN at presentation. There were two patients with subfoveal polyp, five patients with juxtafoveal polyp, and one patient with extrafoveal polyp. Mean vision logMAR at baseline was $1.27 \pm 0.72$ in the hd-PDT group and $0.98 \pm 0.61$ in the monotherapy group. The pretreatment CST mean from OCT was $307.4 \pm 85.2 \mu \mathrm{m}$ in the combination group and 
Table 1. Demographic data and clinical parameters

\begin{tabular}{|l|l|l|l|}
\hline Parameters & $\begin{array}{l}\text { hd-PDT + } \\
\text { anti-VEGF }\end{array}$ & Anti-VEGF & P \\
\hline Number of patients (eyes) & $8(8)$ & $8(10)$ & \\
\hline Average age & 70 & 69.7 & $0.755^{\mathrm{a}}$ \\
\hline Male:female & $4: 4$ & $4: 4$ & $0.664^{\mathrm{b}}$ \\
\hline Laterality (right:left) & $2: 6$ & $4: 6$ & $0.638^{\mathrm{b}}$ \\
\hline BVN & 5 & 0 & $0.007^{\mathrm{b}}$ \\
\hline No previous treatment & 3 & 7 & $0.342^{\mathrm{b}}$ \\
\hline $\begin{array}{l}\text { Previous anti-VEGF injection } \\
- \text { Ranibizumab (range) } \\
\text { - Aflibercept (range) }\end{array}$ & $4.4 \pm 4.2$ & $1.3 \pm 2.2$ & $0.087^{\mathrm{a}}$ \\
\hline $\begin{array}{l}\text { logMAR BCVA } \\
\text { at baseline (Snellen line) }\end{array}$ & $0.1 \pm 3.9(0-10)$ & $0.8 \pm 1.5(0-4)$ & $0.051^{\mathrm{a}}$ \\
\hline CST at baseline $(\mu \mathrm{m})$ & $1.27 \pm 0.7(20 / 372)$ & $0.4 \pm 0.8(0-2)$ & $0.680^{\mathrm{a}}$ \\
\hline
\end{tabular}

hd-PDT: half-dose photodynamic therapy; anti-VEGF: anti-vascular endothelial growth factor; BVN: branching vascular network; BCVA: best-corrected visual acuity; CST: central subfield thickness

aMann-Whitney $\mathrm{U}$ test

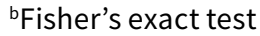

$387.3 \pm 118.5 \mu \mathrm{m}$ in the monotherapy group. Except the number of patients with BVN, there were no statistically significant differences in parameters between the two groups (Table 1 ).

At 6-months post-treatment, the mean of intravitreal anti-VEGF injections received in the combination group was $3.3 \pm 0.9$ for ranibizumab and $0.6 \pm 1.1$ for aflibercept, and $2.7 \pm 1.8$ for ranibizumab and $0.8 \pm 1.0$ for aflibercept in the monotherapy group. No hd-PDT was repeated in these 6 months. The mean CST reduced to $255.8 \pm 76.3 \mu \mathrm{m}$ ( $51.6 \mu \mathrm{m}$ reduction) in the combination group and 284.9 $\pm 135.1 \mu \mathrm{m}(102.4 \mu \mathrm{m}$ reduction) in the monotherapy group. There was greater CST reduction from baseline in the monotherapy group than in the hd-PDT group, but this did not reach statistical significance. Two eyes in the combination group had complete resolution of fluid on OCT, while three eyes had complete resolution of fluid in the monotherapy group. BCVA measured in logMAR after 6 months post-treatment was $1.21 \pm 0.73$ (logMAR 0.06 improvement) in the hd-PDT + anti-VEGF group and $1.00 \pm 0.60$ (logMAR 0.02 deterioration) in the monotherapy group. The combination group showed slightly better visual outcome than monotherapy. The differences in anatomical and functional outcomes between both groups were not statistically significant, as shown in Table 2. 
Table 2. Anatomical and functional outcomes at 6 months post-treatment

\begin{tabular}{|l|l|l|l|}
\hline Parameters & $\begin{array}{l}\text { hd-PDT + anti-VEGF } \\
\text { ( } \mathbf{n}=\mathbf{8} \text { eyes) }\end{array}$ & $\begin{array}{l}\text { Anti-VEGF } \\
\text { ( } \boldsymbol{n}=\mathbf{1 0} \text { eyes) }\end{array}$ & $\boldsymbol{P}$ \\
\hline $\begin{array}{l}\text { Intravitreal anti-VEGF } \\
\text { - Ranibizumab } \\
\text { - Aflibercept }\end{array}$ & $\begin{array}{l}3.9 \pm 1.0 \\
3.3 \pm 0.9 \\
0.6 \pm 1.1\end{array}$ & $\begin{array}{l}3.5 \pm 1.4 \\
2.7 \pm 1.8 \\
0.8 \pm 1.0\end{array}$ & $\begin{array}{l}0.640^{\mathrm{a}} \\
0.582^{\mathrm{a}} \\
0.760^{\mathrm{a}}\end{array}$ \\
\hline $\begin{array}{l}\text { LogMAR BCVA } \\
\text { (Snellen line) }\end{array}$ & $1.21 \pm 0.73(20 / 324)$ & $1.00 \pm 0.60(20 / 200)$ & $0.391^{\mathrm{a}}$ \\
\hline $\begin{array}{l}\text { LogMAR BCVA changes } \\
\text { (logMAR letter) }\end{array}$ & $\begin{array}{l}-0.06(3-\text { letter } \\
\text { improvement) }\end{array}$ & $\begin{array}{l}+0.02(1-\text { letter } \\
\text { deterioration) }\end{array}$ & $0.928^{\mathrm{a}}$ \\
\hline CST, $\mu \mathrm{m}$ & $255.8 \pm 76.3$ & $294.9 \pm 135.1$ & $0.594^{\mathrm{a}}$ \\
\hline CST reduction, $\mu \mathrm{m}$ & 51.6 & 92.4 & $0.214^{\mathrm{a}}$ \\
\hline $\begin{array}{l}\text { Eyes with complete } \\
\text { fluid resorption }(\%)\end{array}$ & $2(25 \%)$ & $3(30 \%)$ & $1.000^{\mathrm{b}}$ \\
\hline
\end{tabular}

hd-PDT: half-dose photodynamic therapy; anti-VEGF: anti-vascular endothelial growth factor; BVN: branching vascular network; BCVA: best-corrected visual acuity; CST: central subfield thickness

aMann-Whitney $\mathrm{U}$ test

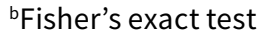

In the hd-PDT group, subretinal haemorrhage occurred in one eye (12.5\%). One eye $(10 \%)$ developed retinal atrophy in the anti-VEGF monotherapy group. No other complications were documented.

\section{Discussion}

Combination of standard PDT with anti-VEGF has been the established strategy for treating PCV provided no contraindication to PDT. Verteporfin is a photoactivated dye that binds to low-density lipoproteins (LDL) and becomes concentrated in the proliferating vascular bed of the neovascular choroid, in which there is increased expression of LDL receptors. Verteporfin is stimulated by the laser energy, causing the release of free radicals and leading to local endothelial cell damage and occlusion of the blood supply to the abnormal vascularisation without significant damage the other normal vessels. ${ }^{18}$ PDT is proven to induce regression of polyps; anti-VEGF is important to allow fluid absorption from the retina and control VEGF upregulation. Therefore, the combination of PDT and anti-VEGF has a synergistic effect on visual and anatomical outcome. 
However, multiple complications of standard PDT have been reported in many studies, including choroidal ischaemia, retinal pigment epithelium atrophy, persistent recurrent exudation, secondary choroidal neovascularisation, and fibrosis that cause poor vision despite PCV regression. ${ }^{19}$ In the TAP and VIP studies, the incidence of VPDT treatment-related serious adverse events was $3.8 \% .^{20,21}$ Thus, several studies showed favourable outcomes with combination of reduced fluence PDT and ranibizumab injection treatment in PCV cases while minimizing the standard PDT side effects. ${ }^{13,22}$ The alternative way to reduce PDT complications is by reducing the verteporfin dose. hd-PDT is also considered to have fewer side effect ${ }^{23}$ while also inducing fluid resorption faster and having a more lasting effect than half-fluence PDT in treating central serous chorioretinopathy (CSCR). ${ }^{15}$ hd-PDT can be considered to treat PCV, as both CSCR and PCV share a similar pathogenesis, which is the hyperpermeability of the underlying choroid. Ian et al. found that hd-PDT combined with intravitreal ranibizumab can cause greater polyp regression in PCV with a single polyp ${ }^{11}$ and was able to produce similar results to standard-PDT at 1 year. ${ }^{12}$ In their retrospective study, Lee et al. showed that hd-PDT caused less damage to the physiologic choroid; however, the complete polyp regression rate at 3 months was lower than for full-dose PDT (43.3\% versus $72.7 \%){ }^{24}$

In our study, BCVA at 6 months improved slightly on combination of hd-PDT and anti-VEGF and deteriorated slightly on anti-VEGF monotherapy. BCVA improvement ( $\log M A R$ 0.06) was superior in the combination group compared to the monotherapy group, although the improvement was statistically not significant. This result is better than reported in lan et al., which showed $0.01 \log$ MAR improvement in the hd-PDT group and 0.03 logMAR improvement in the standard PDT group. ${ }^{12}$ For CST, at 6 months post-treatment both groups had improved, but the monotherapy group showed greater CST reduction, which is similar to the results found by lan et al. Only $20 \%$ of eyes in the combination group had complete fluid resorption whereas $30 \%$ of the monotherapy group achieved complete fluid resorption. The possible explanation for this result was due to the influence of BVN. Five eyes with BVN were detected in our combination group, while there were none in the monotherapy group. BVN has been reported as more resistant to either PDT or anti-VEGF and is the source of recurrent active leaking polyps. ${ }^{25}$ Our results were different from previous studies using half fluence PDT, as our combination group had five eyes $(62.5 \%)$ with BNV and none with BNV in the monotherapy group. Furthermore, the combination group had only three treatment-naïve eyes (37.5\%), with the remaining 5 eyes $(62.5 \%)$ treated with at least four prior anti-VEGF injections, whereas the monotherapy group had seven treatment-naïve eyes (70\%). As a result, patients in the monotherapy group likely had shorter presentation and received treatment earlier than the combination group. Both groups received a similar number of ranibizumab and aflibercept injections for 6 months. In the subanalysis for treatment-naïve patients in both groups, BCVA in the combination group improved significantly (logMAR 0.23 improvement), while the monotherapy group only had a 0.06 
logMAR improvement. However, CST reduction was greater in the monotherapy group than in the combination group with $34.4 \mu \mathrm{m}$ and $83.2 \mu \mathrm{m}$, respectively.

There were no serious side effects documented among these cases. Only one eye $(12.5 \%)$ has subretinal haemorrhage after hd-PDT and one eye (10\%) developed retinal atrophy in the anti-VEGF monotherapy group. This complication percentage in the combination group is lower compared to standard PDT treatment, where an estimated $30 \%$ of patients suffer ocular adverse effects. ${ }^{9,26}$

The limitations of our study include its retrospective, nonrandomized nature, small sample size, short duration of 6 months, heterogeneity of anti-VEGF agents and PCV lesion types, and lack of repeated ICGA at the end of 6 months to assess polyp closure. Additionally, combination therapy tends to be used in patients with BNV or previously failed monotherapy treatment, leading to selection bias. This reflects treatment in the real-world setting. Further prospective, randomized studies with larger sample sizes, longer duration, and standardization of anti-VEGF agents are required to investigate the long-term efficacy and safety of combination hd-PDT treatment compared to single-agent anti-VEGF monotherapy, as well as to identify suitable lesion types for combination therapy.

hd-PDT combined with anti-VEGF was able to produce similar functional outcomes in terms of BCVA when compared to anti-VEGF monotherapy. However, monotherapy has shown to be superior to combination treatment for anatomical improvement but not statistical significance. In conclusion, hd-PDT is a safe and effective treatment for PCV.

\section{Declarations}

\section{Ethics approval and consent to participate}

This study was approved by the Medical Research and Ethics Committee, Ministry of Health Malaysia with the National Medical Research Register number (NMRR-20609-54356).

\section{Competing interests}

None to declare.

\section{Funding}

This study received no funding.

\section{Acknowledgements}

The authors wish to acknowledge statistician Lim Bee Chiu for her contribution to this study. 


\section{References}

1. Wong RL, Lai TY. Polypoidal choroidal vasculopathy: an update on therapeutic approaches. J Ophthalmic Vis Res. 2013;8(4):359. PMID: 24653824

2. Oshima Y, Yasuda M, Kano K, et al. Three-Year Outcomes of Photodynamic Therapy in Age-Related Macular Degeneration and Polypoidal Choroidal Vasculopathy in Japanese Patients. Invest Ophthalmol Vis Sci. 2010;51(13):74.

3. Brown DM, Michels M, Kaiser PK, Heier JS, Sy JP, lanchulev T. Ranibizumab versus verteporfin photodynamic therapy for neovascular age-related macular degeneration: two-year results of the ANCHOR study. Ophthalmology. 2009;116(1):57-65. e5. https://doi.org/10.1016/j.ophtha.2008.10.018

4. Rosenfeld PJ, Brown DM, Heier JS, et al. Ranibizumab for neovascular age-related macular degeneration. N Engl J Med. 2006;355(14):1419-31. https://doi.org/10.1056/NEJMoa054481

5. Heier JS, Brown DM, Chong V, et al. Intravitreal aflibercept (VEGF trap-eye) in wet age-related macular degeneration. Ophthalmology. 2012;119(12):2537-48. https://doi.org/10.1016/j.ophtha.2012.09.006

6. Lee WK, lida T, Ogura Y, et al. Efficacy and safety of intravitreal aflibercept for polypoidal choroidal vasculopathy in the PLANET study: a randomized clinical trial. JAMA Ophthalmol. 2018;136(7):78693. https://doi.org/10.1001/jamaophthalmol.2018.1804

7. Oishi A, Kojima H, Mandai M, et al. Comparison of the effect of ranibizumab and verteporfin for polypoidal choroidal vasculopathy: 12-month LAPTOP study results. Am J Ophthalmol. 2013;156(4):64451. https://doi.org/10.1016/j.ajo.2013.05.024

8. Koh A, Lee WK, Chen LJ, et al. EVEREST study: efficacy and safety of verteporfin photodynamic therapy in combination with ranibizumab or alone versus ranibizumab monotherapy in patients with symptomatic macular polypoidal choroidal vasculopathy. Retina. 2012;32(8):1453-64. https:// doi.org/10.1097/IAE.0b013e31824f91e8.

9. Koh A, Lai TYY, Takahashi K, et al. Efficacy and safety of ranibizumab with or without verteporfin photodynamic therapy for polypoidal choroidal vasculopathy: a randomized clinical trial. JAMA Ophthalmol. 2017;135(11):1206-13. https://doi.org/10.1001/jamaophthalmol.2017.4030

10. Wong CW, Cheung CMG, Mathur R, et al. Three-year results of polypoidal choroidal vasculopathy treated with photodynamic therapy: retrospective study and systematic review. Retina. 2015;35(8):1577-93. https://doi.org/10.1097/IAE.0000000000000499

11. Wong IY, Shi X, Gangwani R, et al. 1-year results of combined half-dose photodynamic therapy and ranibizumab for polypoidal choroidal vasculopathy. BMC Ophthalmol. 2015;15(1):66. https://doi. org/10.1186/s12886-015-0061-8

12. Wong IY, Shi X, Gangwani R, et al. One-year results of half-versus standard-dose photodynamic therapy combined with ranibizumab for polypoidal choroidal vasculopathy. Retina. 2018;38(4):72530. https://doi.org/10.1097/IAE.0000000000001614

13. Sakurai M, Baba T, Kitahashi M, et al. One-year results of intravitreal ranibizumab combined with reduced-fluence photodynamic therapy for polypoidal choroidal vasculopathy. Clin Ophthalmol. 2014;8:235. https://doi.org/10.2147/OPTH.S54578

14. Ricci F, Calabrese A, Regine F, Missiroli F, Ciardella AP. Combined reduced fluence photodynamic therapy and intravitreal ranibizumab for polypoidal choroidal vasculopathy. Retina. 2012;32(7):12808. https://doi.org/10.1097/IAE.0b013e318236e835 
15. Nicoló M, Eandi CM, Alovisi C, et al. Half-fluence versus half-dose photodynamic therapy in chronic central serous chorioretinopathy. Am J Ophthalmol. 2014;157(5):1033-7. https://doi.org/10.1016/j. ajo.2014.01.022

16. Williams PD, Callanan D, Solley W, Avery RL, Pieramici DJ, Aaberg T. A prospective pilot study comparing combined intravitreal ranibizumab and half-fluence photodynamic therapy with ranibizumab monotherapy in the treatment of neovascular age-related macular degeneration. Clin Ophthalmol. 2012;6:1519. https://doi.org/10.2147/OPTH.S31010

17. Tan CS, Ngo WK, Chen JP, Tan NW, Lim TH; EVEREST Study Group. EVEREST study report 2: imaging and grading protocol, and baseline characteristics of a randomised controlled trial of polypoidal choroidal vasculopathy. Br J Ophthalmol. 2015;99(5):624-8. https://doi.org/10.1136/bjophthalmol-2014-305674

18. Newman DK. Photodynamic therapy: current role in the treatment of chorioretinal conditions. Eye (Lond). 2016;30(2):202. https://doi.org/10.1038/eye.2015.251

19. Lee WK, Kim KS, Kim W, Lee SB, Jeon S. Responses to photodynamic therapy in patients with polypoidal choroidal vasculopathy consisting of polyps resembling grape clusters. Am J Ophthalmol. 2012;154(2):355-65. https://doi.org/10.1016/j.ajo.2012.02.019

20. Bressler NM; Treatment of Age-Related Macular Degeneration with Photodynamic Therapy Study Group. Photodynamic therapy of subfoveal choroidal neovascularization in age-related macular degeneration with verteporfin: two-year results of 2 randomized clinical trials-tap report 2. Arch Ophthalmol. 2001;119(2):198-207. https://doi:10-1001/pubs.Ophthalmol.-ISSN-0003-9950-119-2ecs00156

21. Verteporfin in Photodynamic Therapy Study Group. Photodynamic therapy of subfoveal choroidal neovascularization in pathologic myopia with verteporfin. 1-year results of a randomized clinical trialVIP report no. 1. Ophthalmology. 2001;108(5):841-52. https://doi: 10.1016/s0161-6420(01)00544-9.

22. Yoshida Y, Kohno T, Yamamoto M, Yoneda T, Iwami H, Shiraki K. Two-year results of reduced-fluence photodynamic therapy combined with intravitreal ranibizumab for typical age-related macular degeneration and polypoidal choroidal vasculopathy. Jpn J Ophthalmol. 2013;57(3):283-93. https:// doi.org/10.1007/s10384-013-0234-z

23. Chan W-M, Lai TY, Lai RY, Tang EW, Liu DT, Lam DS. Safety enhanced photodynamic therapy for chronic central serous chorioretinopathy: one-year results of a prospective study. Retina. 2008;28(1):85-93. https://doi.org/10.1097/IAE.0b013e318156777f

24. Lee JH, Lee WK. Half-dose photodynamic therapy combined with bevacizumab for polypoidal choroidal vasculopathy. Retina. 2015;35(8):1561-8. https://doi.org/10.1097/IAE.0000000000000498

25. lesato $\mathrm{Y}$, Tanaka M, Murata M, et al. Complete regression of branching vascular network in polypoidal choroidal vasculopathy by ranibizumab and photodynamic therapy, two case reports. BMC Ophthalmol. 2018;18(1):284. https://doi.org/10.1186/s12886-018-0952-6

26. Hirami Y, Tsujikawa A, Otani A, et al. Hemorrhagic complications after photodynamic therapy for polypoidal choroidal vasculopathy. Retina. 2007;27(3):335-41. https://doi.org/10.1097/01. iae.0000233647.78726.46 